\title{
Retinal detachments in patients with AIDS and CMV retinopathy: a role for laser photocoagulation
}

\author{
Peter McCluskey, John Grigg, T Justin Playfair
}

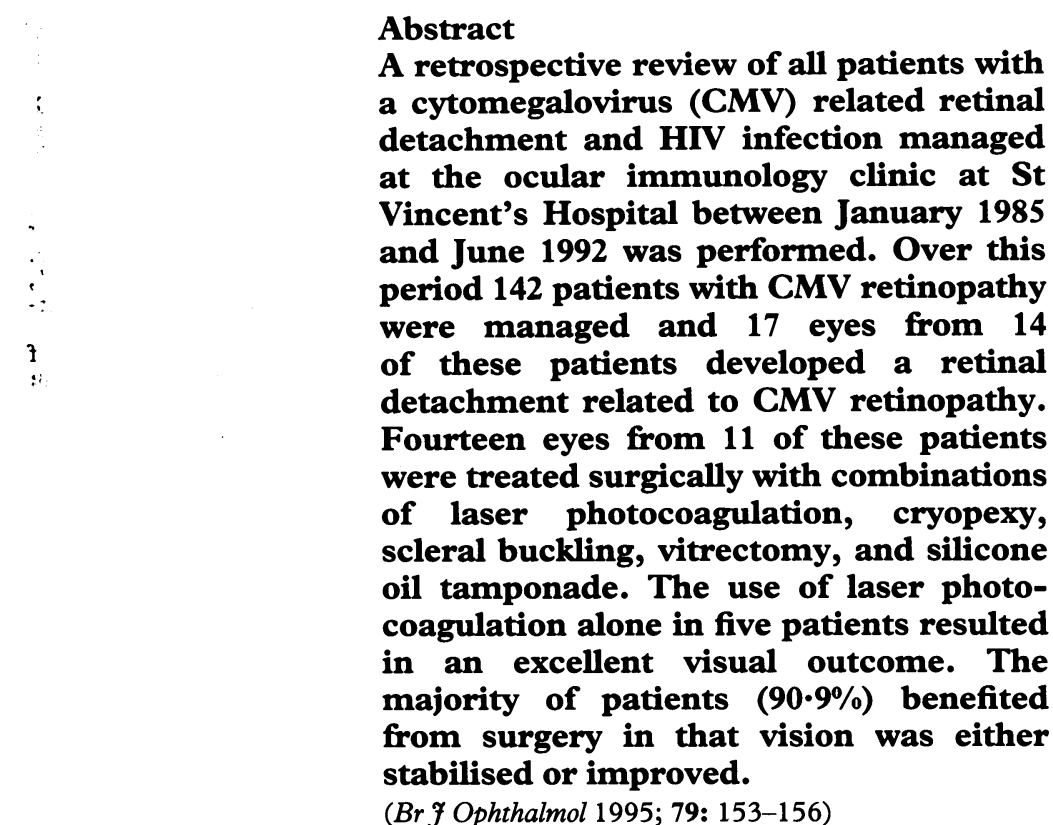

(Br F Ophthalmol 1995; 79: 153-156)

Cytomegalovirus (CMV) retinopathy is the commonest sight threatening manifestation of HIV infection and treatment with ganciclovir or foscarnet significantly improves the visual prognosis and increases patient survival. Retinal detachment is common in patients with CMV retinitis and the surgical management is technically challenging. The lifetime risk of developing a retinal detachment in treated CMV retinitis has been estimated at up to $50 \% .{ }^{1}$ Patients with advanced HIV infection perceive maintenance of vision as crucial to their quality of life and therefore appropriate treatment for retinal detachment complicating CMV retinitis is important to maintain vision and quality of life in such patients.

This study reports the methods and results of treatment in 17 eyes of 14 patients with CMV related retinal detachment and HIV infection managed at a single institution.

\section{Patients and methods}

A retrospective review was performed of all patients with HIV infection seen at the ocular immunology clinic, St Vincent's Hospital in Sydney, Australia, between January 1985 and June 1992, who developed a retinal detachment. Twenty such patients were identified; 14 of the patients (17 eyes) had a retinal detachment as a result of CMV retinitis, three other patients (four eyes) developed retinal detachment in association with acute retinal necrosis, and one patient developed retinal detachment in association with Candida albicans endophthalmitis. Two further patients developed rhegmatogenous retinal detachments unrelated to HIV infection. For this study patients with non-CMV related retinal detachments were excluded.

The study population therefore consisted of 17 eyes from 14 male patients with a mean age of 37.8 years and a mean time from diagnosis of HIV infection to the development of AIDs of $4 \cdot 1$ years with a range of 0 to $8 \cdot 3$ years. The mean CD4 count was 30 cells per millilitre at the time of CMV retinitis diagnosis. For six patients CMV retinitis was the AIDS defining illness while the remaining eight patients developed CMV retinitis on average 13.7 months after the diagnosis of AIDS with a range of 1 to 31 months. The clinical features, management, and visual outcome of the patient group are detailed in Table 1.

Large areas of retina were usually involved by CMV retinitis in these patients. More than $50 \%$ of the retina was involved in eight eyes, between $25 \%$ and $50 \%$ in six eyes, and less than $25 \%$ of the retina in only three eyes. At the time of retinal detachment diagnosis, the CMV retinitis was active in 11 of the 17 eyes. The mean interval between CMV retinitis diagnosis and retinal detachment was 3.95 months. This included retinal detachments present in four eyes at the time of CMV retinitis diagnosis. The range for an eye to develop a retinal detachment was 0 to 12 months. In five eyes the CMV retinitis relapsed before the retinal detachment and in two eyes the CMV retinitis relapsed after the retinal detachment.

The CMV retinitis was treated from the time of diagnosis in all patients with a biphasic ganciclovir treatment regimen consisting of either a 14 or 21 day induction phase using a dose of $5 \mathrm{mg} / \mathrm{kg}$ twice daily, followed by indefinite maintenance therapy of $5 \mathrm{mg} / \mathrm{kg}$ daily 5 days per week. In seven eyes managed with this therapy the CMV retinitis relapsed. Relapse occurred 4.5 months after commencing therapy with a range of 2 to 7 months. Foscarnet was used when patients were unable to tolerate ganciclovir.

In seven eyes the retinal detachment involved one quadrant or less of the fundus. Two quadrants were involved in 10 eyes. Retinal breaks occurred in all quadrants and were seen most commonly in the temporal quadrants. Proliferative vitreoretinopathy was present in four eyes at the time of retinal detachment diagnosis. It was difficult to assess the relation between the vitreous and retina in this group of patients and it was not assessed in 
Table 1 Outcome for retinal detachment in AIDS patiens with cytomegalovirus retinitis

\begin{tabular}{|c|c|c|c|c|c|c|c|c|c|c|c|}
\hline Patient & $\begin{array}{l}\text { Age at } \\
\text { retinal } \\
\text { detachment } \\
\text { (years) }\end{array}$ & Eye & $\begin{array}{l}\text { CMV to } \\
\text { retinal } \\
\text { detachment } \\
\text { (days) }\end{array}$ & $\begin{array}{l}\text { Visual acuity } \\
\text { at retinal } \\
\text { detachment } \\
\text { diagnosis }\end{array}$ & $\begin{array}{l}\text { Retinal } \\
\text { detachment } \\
\text { location by } \\
\text { quadrant }\end{array}$ & $\begin{array}{l}\text { Location } \\
\text { retinal } \\
\text { break relative } \\
\text { to equator }\end{array}$ & $\begin{array}{l}\text { CMV } \\
\text { infection } \\
\text { \% of retina } \\
\text { involved }\end{array}$ & $\begin{array}{l}\text { Treatment } \\
\text { modality }\end{array}$ & $\begin{array}{l}\text { CMV } \\
\text { active } \\
\text { at retinal } \\
\text { detachment }\end{array}$ & $\begin{array}{l}\text { Patient } \\
\text { survival } \\
\text { (months) }\end{array}$ & $\begin{array}{l}\text { Final visual } \\
\text { acuity }\end{array}$ \\
\hline 1 & $38 \cdot 46$ & Right & 166 & $6 / 12$ & $\begin{array}{l}\text { Superior } \\
\text { temporal }\end{array}$ & posterior & 20 & Laser & No & $6 \cdot 80$ & $6 / 12$ \\
\hline 2 & $32 \cdot 55$ & Right & 0 & $6 / 5$ & $\begin{array}{l}\text { Superior } \\
\text { temporal }\end{array}$ & anterior & 10 & Laser & Yes & $5 \cdot 90$ & $6 / 5$ \\
\hline 3 & $29 \cdot 48$ & Right & 142 & $6 / 12$ & $\begin{array}{l}\text { Superior } \\
\text { nasal }\end{array}$ & posterior & 75 & Encirclement & Yes & $3 \cdot 5$ & $\begin{array}{l}\text { Hand } \\
\text { movements }\end{array}$ \\
\hline 3 & & Left & 224 & $6 / 18$ & $\begin{array}{l}\text { Superior } \\
\text { temporal }\end{array}$ & anterior & 50 & None & No & & \\
\hline 4 & $38 \cdot 41$ & Left & 7 & $\begin{array}{l}\text { Count } \\
\text { fingers }\end{array}$ & $\begin{array}{l}\text { Superior } \\
\text { temporal }\end{array}$ & anterior & 30 & None & Yes & $6 \cdot 97$ & $\begin{array}{l}\text { No perception } \\
\text { light }\end{array}$ \\
\hline 5 & $39 \cdot 12$ & Left & 0 & $6 / 7 \cdot 5$ & $\begin{array}{l}\text { Superior } \\
\text { temporal }\end{array}$ & anterior & 10 & Laser & Yes & $4 \cdot 93$ & $6 / 9$ \\
\hline 6 & $48 \cdot 60$ & Right & 268 & $6 / 12$ & $\begin{array}{l}\text { Superior } \\
\text { temporal }\end{array}$ & anterior & 75 & $\begin{array}{l}\text { Encirclement } \\
\text { and silicone } \\
\text { oil }\end{array}$ & Yes & $7 \cdot 30^{\star}$ & Count fingers \\
\hline 6 & & Left & 352 & $6 / 18$ & $\begin{array}{l}\text { Inferior } \\
\text { temporal }\end{array}$ & anterior & 70 & $\begin{array}{l}\text { Encirclement } \\
\text { and silicone } \\
\text { oil }\end{array}$ & Yes & & $6 / 9$ \\
\hline 7 & $36 \cdot 59$ & Left & 122 & $6 / 4$ & $\begin{array}{l}\text { Inferior } \\
\text { nasal }\end{array}$ & posterior & 40 & Laser & No & $28 \cdot 60^{\star}$ & $6 / 5$ \\
\hline 8 & $46 \cdot 05$ & Right & 44 & $6 / 9$ & $\begin{array}{l}\text { Superior } \\
\text { temporal }\end{array}$ & posterior & 30 & $\begin{array}{l}\text { Encirclement } \\
\text { and silicone } \\
\text { oil }\end{array}$ & Yes & $5 \cdot 73^{\star}$ & Count fingers \\
\hline 9 & $31 \cdot 21$ & Right & 0 & $6 / 36$ & $\begin{array}{l}\text { Inferior } \\
\text { temporal }\end{array}$ & posterior & 45 & $\begin{array}{l}\text { Encirclement } \\
\text { and silicone } \\
\text { oil }\end{array}$ & Yes & $8 \cdot 03^{\star}$ & Count fingers \\
\hline 10 & $33 \cdot 39$ & Left & 168 & $6 / 36$ & $\begin{array}{l}\text { Superior } \\
\text { temporal }\end{array}$ & posterior & 40 & Encirclement & No & $9 \cdot 57$ & $6 / 12$ \\
\hline 11 & $37 \cdot 80$ & Right & 19 & $6 / 6$ & $\begin{array}{l}\text { Superior } \\
\text { temporal }\end{array}$ & posterior & 70 & $\begin{array}{l}\text { Encirclement } \\
\text { and silicone } \\
\text { oil }\end{array}$ & Yes & $5 \cdot 30^{\star}$ & $\begin{array}{l}\text { Light } \\
\text { perception }\end{array}$ \\
\hline 11 & & Left & 89 & $6 / 24$ & $\begin{array}{l}\text { Inferior } \\
\text { temporal }\end{array}$ & posterior & 60 & $\begin{array}{l}\text { Encirclement } \\
\text { and silicone } \\
\text { oil }\end{array}$ & Yes & & $6 / 24$ \\
\hline 12 & $44 \cdot 42$ & Left & 357 & $\begin{array}{l}\text { Light } \\
\text { perception }\end{array}$ & $\begin{array}{l}\text { Superior } \\
\text { nasal }\end{array}$ & anterior & 60 & None & No & $1 \cdot 80$ & $\begin{array}{l}\text { No perception } \\
\text { light }\end{array}$ \\
\hline 13 & $34 \cdot 43$ & Left & 0 & $6 / 18$ & $\begin{array}{l}\text { Inferior } \\
\text { temporal }\end{array}$ & posterior & 40 & Laser & Yes & $18 \cdot 37$ & $\begin{array}{l}\text { Light } \\
\text { perception }\end{array}$ \\
\hline 14 & $39 \cdot 27$ & Left & 58 & $6 / 9$ & $\begin{array}{l}\text { Inferior } \\
\text { temporal }\end{array}$ & posterior & 75 & $\begin{array}{l}\text { Encirclement } \\
\text { and silicone } \\
\text { oil }\end{array}$ & No & $4 \cdot 37^{\star}$ & $6 / 18$ \\
\hline
\end{tabular}

^ Patients alive at study endpoint. Patient No 6 had undergone cataract extraction and intraocular lens implantation to his right eye by the study endpoint.

detail routinely in these patients. In no patient was there a definite posterior vitreous detachment as evidenced by the presence of a Vossius ring. At the time of diagnosis 12 eyes $(70 \cdot 6 \%)$ had a visual acuity of $6 / 18$ or better, four eyes $(23.5 \%)$ had a visual acuity between $6 / 18$ and counting fingers, and one eye (5.9\%) had a visual acuity of hand movements.

SURGICAL PROCEDURES

Although the macula was attached in all patients at the time of retinal detachment diagnosis, in two eyes the macula was involved by CMV retinitis and these detachments were not repaired. One further eye had CMV papillitis and this detachment was also not repaired. Thus 14 eyes of 11 patients underwent a surgical procedure for CMV related detachment. All treatment was carried out by the authors. The vitreoretinal surgery was performed by one of the authors (TJP).

The surgical technique used depended on the size and the location of the detachment. For small peripheral detachments involving less than one quadrant and no evidence of proliferative vitreoretinopathy, barrier argon laser retinal photocoagulation was used to surround the detachment. A total of five eyes were treated with laser therapy alone. One other eye was treated with laser therapy initially, but subsequently required further surgery. Laser was applied using either a slitlamp or an indirect ophthalmoscope delivery system. Three rows of confluent burns were placed in the retina around the detachment. The intensity of the laser burns was titrated carefully to the state of the retina which varied from thinned and diaphenous to thickened and oedematous; it was decided to treat cautiously and to retreat areas of retina rather than to risk overtreatment and the development of iatrogenic retinal breaks. Typical initial settings for the slit-lamp laser were $500 \mu \mathrm{m}$ spot size, $400 \mathrm{~mW}$, and $0 \cdot 1$ seconds duration of argon green. With the indirect system similar initial variables were used except that the spot size was fixed at $200 \mu \mathrm{m}$. Up to three treatment sessions were necessary to adequately treat individual patients.

Detachments involving more than one quadrant, detachments threatening the posterior pole, or detachments associated with proliferative vitreoretinopathy were managed by a vitrectomy, membranectomy, and retinotomy with internal drainage of subretinal fluid followed by fluid gas exchange and silicone oil injection. An encircling procedure was performed routinely. In seven eyes the detachment was treated by vitrectomy, silicone oil, and encirclement. In the two remaining eyes, an encirclement procedure alone was used.

\section{Results}

The majority of patients $(90.9 \%)$ benefited from treatment in that vision was either stabilised or improved. Seven patients $(50 \%)$ retained a visual acuity of $6 / 18$ or better, while four patients $(28 \cdot 5 \%)$ had a visual acuity 


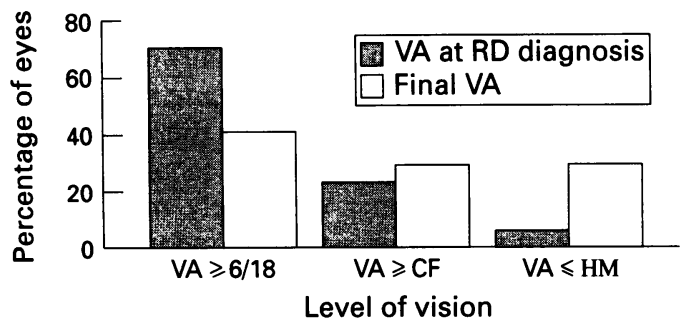

Figure 1 Visual acuity in cytomegalovirus retinal detachment before and after treatment.

between $6 / 18$ and counting fingers. The remaining three patients $(21.5 \%)$ had visual acuities of hand movements or worse. Four of the five eyes $(80 \%)$ treated with laser achieved a final visual acuity of $6 / 18$ or better, whereas only three of the nine eyes $(33 \%)$ treated by surgery achieved $6 / 18$ or better (Figs 1 and 2). All eyes treated with either laser or surgery were stabilised in that the retina was completely reattached or the detached area of retina was stabilised and did not increase in size over time. Redetachment occurred in one patient who had been treated by scleral buckling and cryotherapy. This detachment was not repaired as the macula had been destroyed by a relapse of CMV retinitis.

Complications related specifically to silicone oil occurred in two patients and consisted of one patient who developed bilateral cataracts approximately 3 months after surgery and subsequently underwent cataract surgery in one eye. A planned extracapsular lens extraction was performed without intraocular lens implantation. The other patient developed pupil block glaucoma as a result of intraoperative zonular dehiscence and resultant silicone oil migration into the anterior chamber. This patient required a surgical peripheral iridectomy and removal of silicone oil. In one other patient there was delayed progression of the detachment following initial laser therapy to an inferior temporal retinal detachment. This patient developed new superior temporal retinal breaks and detachment which required a vitrectomy, silicone oil tamponade, and scleral buckle to reattach the retina.

A modified Kaplan Meier survival analysis revealed a median survival time of 7.6 months after the initial treatment for retinal detachment. One patient remains alive $2^{1 / 2}$ years after treatment. At the study endpoint six of the 14 patients remain alive (Fig 3 ).

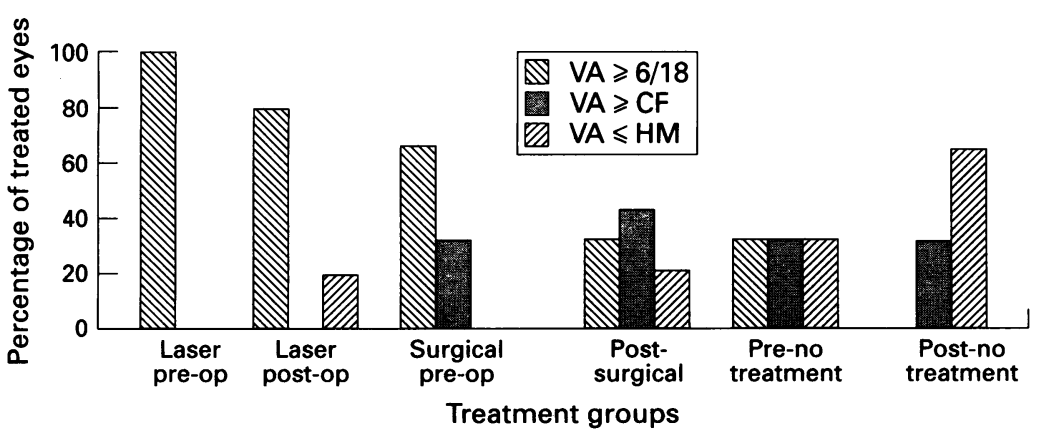

Figure 2 Visual outcome for each treatment modality.

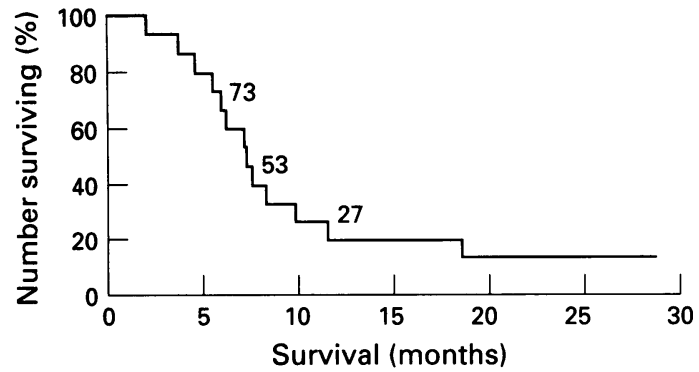

Figure 3 Survival after treatment. (Mean survival $7 \cdot 6$ months.)

\section{Discussion}

Since 1985 the incidence of CMV retinitis has been increasing and this has been followed by an increase in CMV related retinal detachment. In this series the prevalence of CMV related retinal detachment was $10 \cdot 6 \%$, which is lower but comparable with other published series where rates from $11 \cdot 7 \%$ to $29 \%$ have been observed. ${ }^{3-8}$ There were two distinct ocular presentations in this study: four eyes which presented with a retinal detachment and active CMV retinitis at the time of initial CMV diagnosis and 13 eyes which developed a retinal detachment at some time following CMV retinitis diagnosis. In these eyes, the retinitis was active in seven eyes and regressed in six eyes. Jabs $e t a l^{1}$ have data which shows that retinal detachment is related to the extent of retinal involvement by $\mathrm{CMV}$ and that treatment delays the onset of retinal detachment. In the 13 eyes which developed detachments after CMV retinitis diagnosis, the mean time to the development of retinal detachment was 155 days. Other studies ${ }^{4} 7$ have suggested that antiviral drugs hasten the development of the retinal detachment. This study suggests that retinal detachment occurs once the retinitis has been treated for a considerable period in the majority of patients and that treatment delays the onset of detachment.

Visual acuity remained relatively stable after surgical or laser intervention (Figs 1 and 2). Dramatic improvement in postoperative visual acuity rarely occurred. The best predictor of visual outcome in this series, as in other series, was the preoperative visual acuity. ${ }^{35}$ Patients with CMV related retinal detachments survived for a mean of 7.6 months after treatment. The increasing survival time for patients with CMV related retinal detachments means that appropriate treatment can greatly improve their quality of life by reducing morbidity without affecting the long term visual outcome. Good vision can be maintained in $63.7 \%$ of the treated patients, and mobility vision achieved in $90.9 \%$ of the treated patients.

This study agrees with other series ${ }^{12410}$ in that the preferred treatment option for extensive retinal detachments, those involving or threatening the macula, or those with proliferative vitreoretinopathy, is a vitrectomy and silicone oil tamponade. With this technique, the retina remained attached in the seven eyes treated in this way. The visual results with silicone oil tamponade are poorer than with other forms of detachment surgery and there may be significant visual loss at the time of surgery or 
postoperatively from compromise to the retinal and optic nerve circulation. There is also a large refractive shift following silicone oil surgery which impairs vision postoperatively. The visual results from the silicone oil treated group in this study show an obvious reduction in vision postoperatively, but five of the seven eyes retained mobility vision after surgery.

The results of this study are similar to those reported by Orellana et $a l^{3}$ in that a large percentage $(35.7 \%)$ of the retinal detachments were treated by laser photocoagulation alone, and the results of both studies differ from other recently reported series, ${ }^{59}$ where only the results of operative surgical procedures have been reported. The eyes treated with laser photocoagulation in this study form a group of patients who had localised retinal detachments involving less than one quadrant and with less than $50 \%$ of the retina involved by CMV retinitis. Visual acuity was $6 / 18$ or better in all eyes. The results show that these patients had an excellent visual prognosis when compared with those treated by other modalities. In four patients in this study, retinal detachment was diagnosed at the time of CMV retinitis diagnosis and in three eyes the detachment was suitable for laser photocoagulation. Thus, there may be at least two subsets of patients who develop CMV related retinal detachment. One group, who present with peripheral CMV retinitis associated with retinal breaks and localised retinal detachment with no past history of CMV retinitis or treatment, who are suitable for laser treatment, and have a good visual prognosis. The second group are known to have extensive CMV retinitis and present a considerable time after retinitis diagnosis with more extensive retinal breaks and detachments.
These patients have a poorer visual prognosis and usually require a vitrectomy and silicone oil tamponade to reattach the retina.

It is therefore important to identify peripheral, localised detachments which may be effectively managed with laser photocoagulation. Good vision is a major concern in patients with advanced HIV infection and laser photocoagulation is a useful treatment modality in selected patients which prevents progression of retinal detachment and maintains vision without the need for operative surgery.

1 Jabs DA, Enger C, Haller J, DeBustros S. Retinal detachment in patients with cytomegalovirus retinitis. Arch ment in patients with cytom

2 Regillo CD, Vander JF, Duker JS, Fischer DH, Belmont JB, Kleiner R. Repair of retinitis related retinal detachments with silicone oil in patients with acquired immunodeficiency syndrome. Am $\mathcal{F}$ Ophthalmol 1992; 113: 21-7.

3 Orellana J, Teich SA, Lieberman RM, Restrepo S, Peaire R Treatment of retinal detachments in patients with the acquired immune deficiency syndrome. Ophthalmology 1991; 98: 939-43.

4 Freeman WR, Henderly DE, Wan WL, Causey D, Trousdale M, Green RL, et al. Prevalence, pathophysiology, and treatment of rhegmatogenous retinal detachment in treated cytomegalovirus retinitis. Am $f$ Ophthalmol in treated cytomegalo.

5 Sidikaro Y, Silver L, Holland GN, Kreiger AE. Rhegmatogenous retinal detachments in patients with AIDS and necrotizing retinal infections. Ophthalmology 1991; 98: 129-35.

6 Orellana J, Teich SA, Friedman AH, Lerebours F, Winterkorn J, Mildvan D. Combined short- and longterm therapy for the treatment of cytomegalovirus retinitis using ganciclovir (BW B759U). Ophthalmology 1987; 94: 831-8.

7 Holland GN, Sidikaro Y, Krieger AE, Hardy D, Sakamoto MJ, Frenkel LM, et al. Treatment of cytomegalovirus retinopathy with ganciclovir. Ophthalmology 1987; 94: retinopathy.

8 Jabs DA, Newman C, DeBustros S, Polk BF. Treatment of cytomegalovirus retinopathy with ganciclovir. Ophthalmology 1987; 94: 824-30.

9 Chuang EL, Davis JL. Management of retinal detachmen associated with CMV retinitis in AIDS patients. Eye 1992 6: $28-34$.

10 Holland GN. The management of retinal detachments in patients with the acquired immune deficiency syndrome. Arch Ophthalmol 1991; 109: 791-3. 